\title{
PREDIKSI FINANCIAL DISTRESS MENGGUNAKAN MODEL ZMIJEWSKI DAN MODEL GROVER PADA PERUSAHAAN MIGAS DI BEI
}

\author{
Ni Wayan Yulia Krusita ${ }^{1}$ \\ Ni Luh Putu Wiagustini ${ }^{2}$
}

${ }^{1,2}$ Fakultas Ekonomi dan Bisnis Universitas Udayana (Unud), Bali, Indonesia e-mail : krusita.yuliaa@ gmail.com

\begin{abstract}
ABSTRAK
Penelitian ini bertujuan untuk memprediksi financial distress dengan menggunakan model Zmijewski dan model Grover. Populasi dalam penelitian ini adalah tujuh perusahaan minyak dan gas bumi di Bursa Efek Indonesia tahun 2012-2017. Metode pengambilan sampel yang digunakan dalam penelitian ini adalah penyampelan jenuh. Penelitian ini menggunakan model Zmijewski dan model Grover untuk memprediksi financial distress. Hasil prediksi financial distress menggunakan model Zmijewski tahun 2012 dan 2013 diprediksi Radiant Utama Interinsco Tbk mengalami financial distress, tahun 2014 semua perusahaan diprediksi tidak mengalami financial distress, tahun 2015 diprediksi Energi Mega Persada Tbk dan Medco Energi Internasional Tbk mengalami financial distress, tahun 2016 diprediksi Energi Mega Persada Tbk dan Benakat Integra Tbk mengalami financial distress dan tahun 2017 diprediksi Energi Mega Persada Tbk mengalami financial distress. Hasil prediksi financial distress menggunakan model Grover tahun 2012-2014 semua perusahaan diprediksi tidak mengalami financial distress, tahun 2015 dan 2016 diprediksi Benakat Integra Tbk dan Energi Mega Persada Tbk mengalami financial distress dan tahun 2017 diprediksi Benakat Integra Tbk mengalami financial distress serta diprediksi Energi Mega Persada Tbk dan Surya Esa Perkasa Tbk berada pada grey area.

Kata kunci : financial distress, model zmijewski dan model grover
\end{abstract}

\begin{abstract}
This study aims to predict financial distress by using Zmijewski model and Grover model. The population in this study were seven oil and gas companies on the Indonesia Stock Exchange in 2012-2017. The sampling method used in this study was saturated sampling. This study uses Zmijewski model and Grover model to predict financial distress. The prediction results of financial distress using Zmijewski model in 2012 and 2013 predicts Radiant Utama Interinsco Tbk to experience financial distress, in 2014 predicts that all companies not experience financial distress, in 2015 predict Energi Mega Persada Tbk and Medco Energi Internasional Tbk to experience financial distress, in 2016 predict Energi Mega Persada Tbk and Benakat Integra Tbk to experience financial distress and in 2017 predict Energi Mega Persada Tbk to experience financial distress. The prediction results of financial distress using Grover model from 2012-2014 predict that all companies not experience financial distress, in 2015 and 2016 predict Benakat Integra Tbk and Energi Mega Persada Tbk to experience financial distress and in 2017 predict Benakat Integra Tbk to experience financial distress and predict Energi Mega Persada Tbk and Surya Esa Perkasa Tbk are in the grey area.
\end{abstract}

Keywords : financial distress, zmijewski model and grover model 


\section{PENDAHULUAN}

Perusahaan didirikan bertujuan untuk menghasilkan laba, sehingga perusahaan tersebut dapat bertahan dan berkembang dalam jangka panjang. Seperti perusahaan minyak dan gas bumi didirikan bertujuan untuk menghasilkan laba, sehingga diharapkan perusahaan dapat bertahan dan berkembang dalam jangka panjang serta tidak mengalami likuidasi. Namun faktanya hal tersebut tidak selalu menjadi kenyataan, seperti fenomena yang terjadi baru-baru ini produksi minyak dan gas bumi yang mengalami penurunan dari tahun ke tahun yang berdampak pada kelangsungan usaha perusahaan minyak dan gas bumi (SKK Migas, 2018). Berikut ini akan disajikan gambar laju penurunan/kenaikan produksi minyak dan gas bumi tahun 2012-2017.

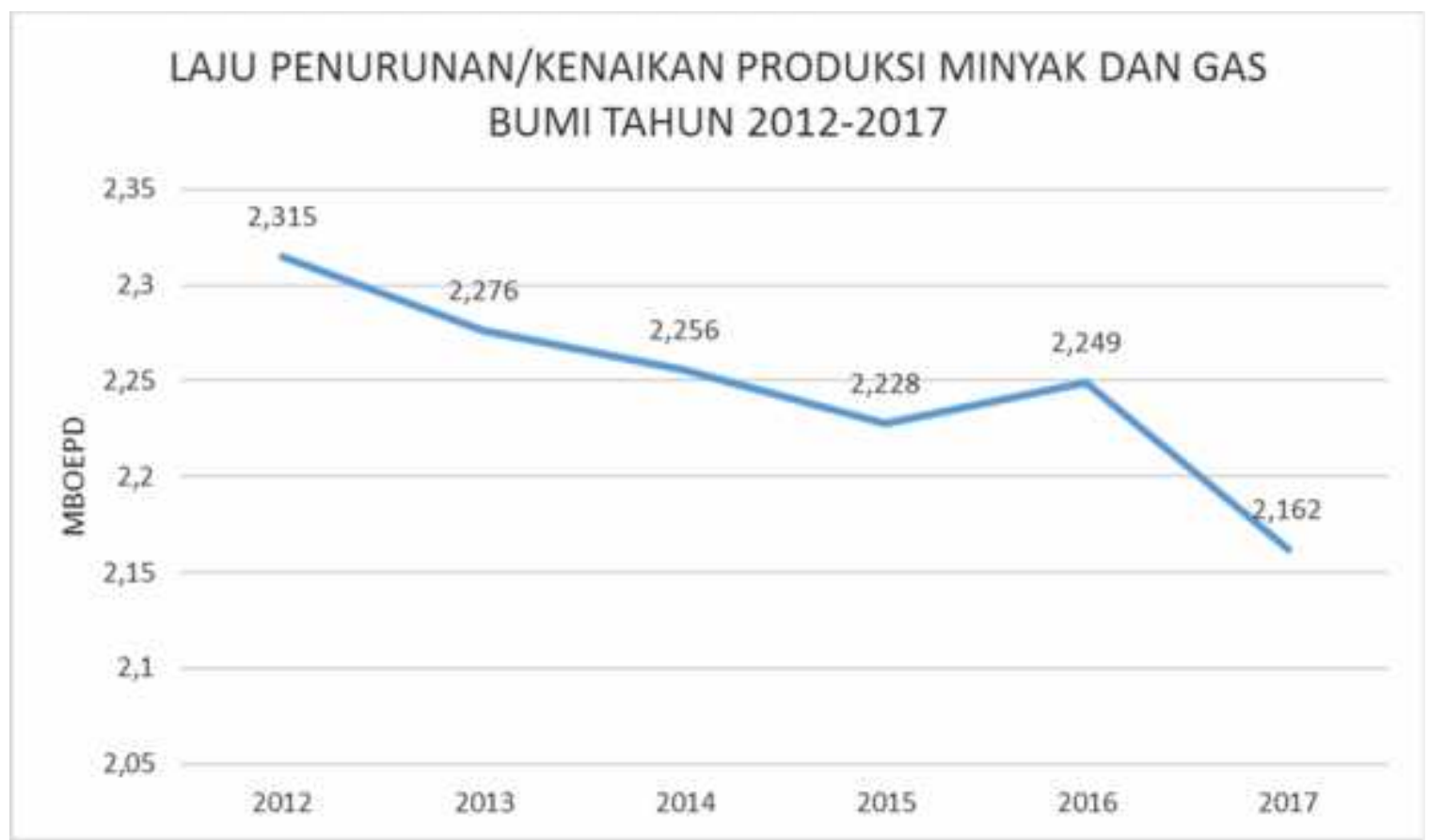

Grafik 1. Laju Penurunan/Kenaikan Produksi Minyak dan Gas Bumi Tahun 2012-2017

Sumber : SKK Migas, 2018 
Grafik 1. menunjukkan bahwa produksi minyak dan gas bumi dari tahun 2012-2017 cenderung mengalami penurunan. Produksi minyak dan gas bumi yang cenderung menurun dari tahun 2012-2017 sesuai dengan data tersebut, berdampak pada pendapatan perusahaan yang bergerak dalam bidang sub sektor pertambangan minyak dan gas bumi yang cenderung mengalami penurunan. Pendapatan perusahaan yang cenderung mengalami penurunan dan ditambah perkembangan ekonomi global dapat mengakibatkan kebangkrutan pada perusahaan apabila perusahaan tidak mampu memperkuat fundamental manajemennya (Putra dan Arlin, 2014).

Kebangkrutan merupakan kondisi ketika perusahaan tidak dapat melakukan kegiatan operasional perusahaan karena mengalami financial distress parah (Prihantini dan Maria, 2013). Kordestani (2011) menjabarkan kebangkrutan terdiri dari 4 tahapan yaitu latency, shortage of cash, financial distress dan bangkruptcy. Financial distress merupakan tahapan yang mendekati kebangkrutan yang biasanya ditandai dengan profitabilitas perusahaan yang tidak pasti pada tahun berikutnya (Putera dkk., 2016). Menurut Xie et al. (2010) financial distress juga dapat diartikan suatu kondisi dimana perusahaan tidak dapat memenuhi atau mengalami kesulitan membayar kewajiban keuangan kepada kreditornya. Kesulitan keuangan (financial distress) pada sebuah perusahaan dapat di analisis menggunakan indikator kinerja keuangan perusahaan sehingga kondisi financial distress dapat diteliti sebelum hal tersebut benar-benar terjadi (Dewi dan Dana, 2017). Gejala financial distress yang diketahui diawal akan membantu pihak manajemen dalam mengambil keputusan perbaikan kondisi 
keuangan sejak awal, sehingga perusahaan dapat terhindar dari financial distress. Potensi financial distress dapat diketahui dari hasil perhitungan model prediksi financial distress seperti model grover dan zmijewski (Kleinert, 2014).

Prediksi financial distress menggunakan model-model prediksi financial distress telah banyak dilakukan sebelumnya dan ditemukan beberapa hasil. Husein dan Galuh (2014), Januri et al. (2017) serta Salim (2017) dalam penelitiannya mendapatkan hasil model zmijewski paling tepat digunakan untuk memprediksi financial distress perusahaan. Ulfa dkk. (2018) dalam penelitiannya menyatakan bahwa metode springate dan metode grover mampu memprediksi potensi kebangkrutan perusahaan otomotif pada periode 2012-2016, sedangkan metode altman z-score dan zmijewski tidak mampu untuk memprediksi potensi kebangkrutan perusahaan otomotif pada periode 2012-2016. Aminian et al. (2016), Prihanthini dan Maria (2013), Margali dkk. (2017) serta Pakdaman (2018) dalam penelitiannya menyatakan bahwa dalam memprediksi kebangkrutan model prediksi yang paling akurat digunakan adalah model Grover. Primasari (2017) dalam penelitiannya mendapatkan hasil bahwa model grover tidak tepat digunakan dalam memprediksi financial distress. Desmawati dkk. (2016) pada penelitiannya di perusahaan industri manufaktur di Indonesia mendapatkan hasil bahwa model Altman Z-score, model Springate, model Grover, dan model Zmijewski tidak menunjukkan ketepatan dalam memprediksi kebangkrutan.

Berdasarkan penelitian terdahulu tersebut diketahui bahwa terdapat perbedaan hasil. Perbedaan penelitian dengan penelitian-penelitian terdahulu terletak pada objek penelitian, teknik pengumpulan sampel serta periode 
penelitian yang berbeda. Objek yang disasar dalam penelitian ini adalah perusahaan minyak dan gas bumi (migas) di Bursa Efek Indonesia tahun 20122017. Berdasarkan uraian-uraian tersebut, maka rumusan masalah dalam penelitian ini adalah bagaimana prediksi financial distress dengan menggunakan model zmijewski pada perusahaan migas di Bursa Efek Indonesia? dan bagaimana prediksi financial distress dengan menggunakan model grover pada perusahaan migas di Bursa Efek Indonesia?. Tujuan dari penelitian ini adalah untuk memprediksi financial distress menggunakan model zmijewski serta model grover pada perusahaan migas di Bursa Efek Indonesia.

Financial distress ialah keadaan kesulitan pada keuangan yang dialami perusahaan akibat dari arus kas keluar perusahaan lebih besar daripada arus kas masuknya. Financial distress menyebabkan perusahaan tidak dapat memenuhi kewajibannya, sehingga apabila kondisi ini tidak diatasi maka perusahaan tersebut akan mengalami kebangkrutan (Djamaluddin et al., 2017). Simanjuntak dkk. (2017) menyatakan financial distress merupakan suatu kondisi kesulitan keuangan dalam perusahaan berupa penuruan perolehan laba, ketidakmampuan perusahaan dalam melunasi hutang serta kewajiban yang disajikan berdasarkan laporan keuangan dengan membandingkan laporan keuangan periode sebelumnya. Menurut Hidayat (2014) terdapat beberapa definisi kesulitan keuangan menurut tipenya, yaitu (1) Economic failure adalah kondisi saat pendapatan perusahaan tidak cukup untuk menutupi total biaya termasuk biaya modal. (2) Business failure adalah kondisi bisnis yang menghentikan operasinya karena mengalami kerugian. (3) Technical insolvency keadaan ketika perusahaan tidak dapat 
memenuhi kewajiban lancarnya ketika jatuh tempo. (4) Insolvency in bankruptcy terjadi ketika nilai buku hutang perusahaan melebihi nilai pasar aset saat ini. (5) Legal banckruptcy adalah keadaan ketika perusahaan dikatakan mengalami kebangkrutan secara hukum apabila perusahaan tersebut mengajukan tuntutan secara resmi sesuai dengan undang-undang yang berlaku. Tiga faktor penyebab financial distress (kesulitan keuangan) ditinjau dari aspek keuangan perusahaan yaitu ketidakcukupan modal, kekurangan dana dan besarnya beban hutang dan bunga dan mengalami kerugian (Desmawati dkk., 2016).

Altman tahun 1968 menggunakan model step-wise multivariate discriminantanalysis (MDA) dalam penelitiannya. Terdapat lima rasio yang digunakan Altman dimasukkan kedalam analisis MDA yaitu adalah working capital/total assets, retained earning/total assets, EBIT/total assets, market value of equity/total liabilities dan sales/total assets (Fatmawati, 2012).

Model Springate tahun 1978 merupakan model prediksi kebangkrutan yang dibuat mengikuti prosedur model Altman. Model ini memperhatikan empat rasio keuangan untuk memprediksi financial distress yaitu rasio working capital/total assets, net profit before interest and taxes/total assets, net profit before taxes/current liabilities, dan sales/total assets (Priambodo, 2017).

Model Ohlson tahun 1980 terinspirasi oleh penelitian-penelitian sebelumnya, juga melakukan studi mengenai financial distress. Terdapat beberapa modifikasi yang lakukan dalam dibanding penelitian-penelitian sebelumnya. Model yang dibangun Ohlson memiliki 9 variabel yang terdiri dari beberapa rasio 
keuangan. Ohlson tahun 1980 menyatakan bahwa model ini memiliki cutoff point optimal pada nilai 0,38 (Wulandari dkk., 2014).

Model Fulmer tahun 1984 menggunakan metode step - wise multiple discriminate analysis untuk mengevaluasi 40 rasio keuangan yang diterapkan untuk sampel 60 perusahaan. Model Fulmer yang dikembangkan ini memperhatikan sembilan rasio keuangan seperti laba ditahan terhadap total aktiva, penjualan terhadap total aktiva, laba sebelum pajak terhadap total ekuitas, arus kas terhadap total kewajiban, total kewajiban terhadap total aset, total kewajiban lancar terhadap total aktiva, log total asset berwujud, modal kerja terhadap total kewajiban dan log laba sebelum bunga dan pajak terhadap beban bunga (Ambarwati dkk., 2016).

Zmijewski (1984) menggunakan teknik probit untuk membangun model prediksi kebangkrutannya. Sampel estimasi akhir dari studi Zmijewski tahun 1984 berisi 40 perusahaan bangkrut dan 800 perusahaan yang tidak bangkrut (Avenhuis, 2013). Model zmijewski dalam memprediksi kebangkrutan perusahaan memperhatikan rasio-rasio keuangan seperti (1) ROA digunakan untuk mengukur kemampuan perusahaan dalam memanfaatkan aktivanya untuk memperoleh laba. (2) Leverage adalah rasio yang digunakan untuk mengukur sampai seberapa jauh perusahaan dibiayai oleh dana pinjaman (Wiagustini, 2014:87). Debt ratio termasuk dalam rasio leverage yang membandingkan total pinjaman dengan aktiva dikalikan $100 \%$, untuk mengetahui besarnya penggunaan hutang dibandingkan seluruh modal perusahaan (Wiagustini, 2014:88). (3) Likuiditas mengambarkan kemampuan perusahaan dalam memenuhi kewajiban 
Ni Wayan Yulia Krusita, Prediksi Financial Distress...

jangka pendeknya pada saat jatuh tempo (Wiagustini, 2014:86). Current Ratio termasuk dalam rasio likuiditas yang mengukur kemampuan perusahaan memenuhi kewajibannya yang segera jatuh tempo. Model zmijewski mempunyai cut off yaitu perusahaan diprediksi mengalami kebangkrutan apabila hasil perhitungan yang diperoleh perusahaan dengan menggunakan model ini melebihi $0(X>0)$. Sebaliknya, perusahaan dikategrikan sehat apabila perusahaan memiliki skor kurang dari $0(\mathrm{X}<0)$.

Model CA-Score ini menggunakan langkah Multiple Discriminant Analysis. Dari hasil perhitungan model Springate diperoleh nilai CA-Score yang dibagi dalam dua kategori yaitu nilai CA-Score $<-0,3$ maka perusahaan termasuk dalam kategori tidak pailit dan sebaliknya apabila nilai CA-Score > -0,3 maka perusahaan termasuk dalam kategori pailit (Wulandari dkk, 2014).

Model grover adalah model prediksi yang terbentuk dari proses penilaian dan pendesainan ulang model altman Z-Score. Model grover menggunakan sampel sesuai dengan model Altman Z-score pada tahun 1968 yaitu menggunakan 70 perusahaan dengan 35 perusahaan yang bangkrut dan 35 perusahaan yang tidak bangkrut pada tahun 1982 sampai 1996 (Putra dan Rahma, 2016). Model ini memperhatikan rasio-rasio keuangan seperti (1) Working capital to total asset (modal kerja terhadap total aset) yang digunakan untuk menunjukkan kemampuan perusahaan untuk menghasilkan modal kerja bersih dari total aktiva. (2) Earnings before interest and taxes to total assets digunakan untuk mengukur produktivitas yang sebenarnya dari aktiva perusahaan. Rasio tersebut mengukur kemampuan perusahaan dalam mengahsilkan laba dari aktiva yang digunakan (Kurniawati dan 
Nur, 2016). (3) ROA digunakan untuk mengukur kemampuan perusahaan dalam memanfaatkan aktivanya untuk memperoleh laba. ROA ini didapatkan melalai perbandingan laba bersih perusahaan dengan total aktiva dikalikan $100 \%$ (Wiagustini, 2014:90). Model grover mempunyai cut off perusahaan dikategorikan dalam keadaan bangkrut apabila skor yang diperoleh perusahaan berdasarkan pada perhitungan model ini adalah kurang dari atau sama dengan $-0,02(\mathrm{G} \leq-0,02)$. Sedangkan apabila skor lebih dari atau sama dengan $0,01(\mathrm{G} \geq 0,01)$ maka perusahaan dikategorikan dalam keadaan sehat (Grover, 2003). Perusahaan yang memiliki skor diantara batas atas dan batas bawah dikategorikan berada pada grey area (Primasari, 2017).

\section{METODE PENELITIAN}

Penelitian ini merupakan deskriptif. Penelitian ini berlokasi pada perusahaan migas yang terdaftar di BEI. Obyek penelitian adalah kondisi financial distress perusahaan migas di BEI periode 2012-2017. Variabel yang digunakan adalah adalah rasio model Zmijewski dan model Grover yang meliputi debt ratio, current ratio, return on assets, working capital to total assets, dan earnings before interest and tax to total assets. Definisi operasinal masing-masing variabel adalah sebagai berikut yaitu debt ratio dihitung dengan membandingkan total kewajiban dengan total aktiva yang dimiliki oleh perusahaan dikalikan $100 \%$, current ratio dihitung dengan membandingkan aset lancar yang dimiliki perusahaan dengan kewajiban lancar perusahaan dikalikan 100\%, ROA dihitung dengan membandingkan laba bersih dengan total asset dikalikan $100 \%$, working capital to total asset dihitung dengan membandingkan aset lancar dikurangi kewajiban 
dengan total asset dikalikan $100 \%$, dan earning before interest and taxes to total asset dihitung dengan membandingkan laba sebelum bungan pajak dengan total asset dikalikan $100 \%$.

Populasi penelitian ialah perusahaan migas di BEI tahun 2012-2017 yaitu Ratu Prabu Energi Tbk (ARTI), Benakat Integra Tbk (BIPI), Elnusa Tbk (ELSA), Energi Mega Persada Tbk (ENRG), Surya Esa Perkasa Tbk (ESSA), Medco Energi International Tbk (MEDC), dan Radiant Utama Interisco Tbk (RUIS).

Metode pengumpulan sampelnya adalah metode penyampelan jenuh (saturated sampling). Penelitian ini menggunakan teknik observasi nonpartisipan dalam mengumpulkan data. Jenis data yang digunakan adalah data kuantitatif/data dalam bentuk angka dan data sekunder yang dapat diakses melalui website resmi IDX yaitu.

Teknik analisis data yang dilakukan meliputi menghitung rasio keuangan dan menghitung prediksi financial distress dengan model zmijewski serta model grover yaitu:

Persamaan model zmijewski adalah:

$X=-4,3-4,5 X 1+5,7 \times 2-0,004 X 3$

Keterangan :

$\mathrm{X} 1=R O A$

$\mathrm{X} 2=$ Leverage $($ Debt Ratio $)$

$\mathrm{X} 3=$ Likuiditas (Current Ratio)

Perusahaan diprediksi mengalami financial distress (kesulitan keuangan) apabila suatu perusahaan mendapatkan $X$ lebih dari $0 \quad(X>0)$. Sebaliknya, perusahaan diprediksi dalam keadaan sehat apabila skor $\mathrm{X}$ kurang dari $0(\mathrm{X}<0)$. 
Persamaan model grover adalah:

$\mathrm{G}=1,650 \mathrm{X} 1+3,404 \mathrm{X} 2-0,016 \mathrm{ROA}+0,057$

Keterangan :

$\mathrm{X} 1=$ Working Capital to Total assets

$\mathrm{X} 2=$ Earnings Before Interest and Taxes to Total Assets

$\mathrm{ROA}=$ Net Income/Total Assets

Perusahaan yang memiliki skor $G$ kurang dari atau sama dengan $-0,02(\mathrm{G} \leq$ $-0,02)$ diprediksi berada pada kondisi financial distress. Sedangkan apabila skor G lebih dari atau sama dengan $0,01(\mathrm{G} \geq 0,01)$ perusahaan diprediksi dalam kondisi sehat (Grover, 2003). Perusahaan dengan skor hasil perhitungan $\mathrm{G}$ berada diantara batas atas dan batas bawah $(0,01<\mathrm{G}>-0,02)$ diprediksi berada pada keadaan grey area (Primasari, 2017).

HASIL DAN PEMBAHASAN

Tabel 1.

Prediksi Financial Distress menggunakan Model Zmijewski pada Perusahaaan Migas

\begin{tabular}{|c|c|c|c|c|c|c|}
\hline Perusahaan & Tahun & $\begin{array}{c}\text { X1 } \\
\text { (ROA) }\end{array}$ & $\begin{array}{c}\text { X2 (Debt } \\
\text { ratio) }\end{array}$ & $\begin{array}{c}\mathrm{X3} \\
\text { (Current } \\
\text { ratio) }\end{array}$ & Zmijewski & Prediksi \\
\hline \multirow[t]{6}{*}{ ARTI } & 2012 & $4 \%$ & $40 \%$ & $152 \%$ & $-2,17475$ & NON DISTRESS \\
\hline & 2013 & $4 \%$ & $41 \%$ & $360 \%$ & $-2,15727$ & NON DISTRESS \\
\hline & 2014 & $2 \%$ & $45 \%$ & $208 \%$ & $-1,79417$ & NON DISTRESS \\
\hline & 2015 & $1 \%$ & $31 \%$ & $482 \%$ & $-2,57572$ & NON DISTRESS \\
\hline & 2016 & $0 \%$ & $34 \%$ & $316 \%$ & $-2,39936$ & NON DISTRESS \\
\hline & 2017 & $1 \%$ & $30 \%$ & $674 \%$ & $-2,68048$ & NON DISTRESS \\
\hline Perusahaan & Tahun & $\begin{array}{c}\text { X1 } \\
\text { (ROA) }\end{array}$ & $\begin{array}{l}\text { X2 (Debt } \\
\text { ratio) }\end{array}$ & $\begin{array}{c}\text { X3 } \\
\text { (Current } \\
\text { ratio) }\end{array}$ & Zmijewski & Prediksi \\
\hline \multirow[t]{6}{*}{ BIPI } & 2012 & $0 \%$ & $17 \%$ & $209 \%$ & $-3,35574$ & NON DISTRESS \\
\hline & 2013 & $2 \%$ & $65 \%$ & $53 \%$ & $-0,69198$ & NON DISTRESS \\
\hline & 2014 & $2 \%$ & $66 \%$ & $68 \%$ & $-0,63996$ & NON DISTRESS \\
\hline & 2015 & $0 \%$ & $66 \%$ & $34 \%$ & $-0,53725$ & NON DISTRESS \\
\hline & 2016 & $-13 \%$ & $77 \%$ & $5 \%$ & 0,681574 & DISTRESS \\
\hline & 2017 & $3 \%$ & $74 \%$ & $14 \%$ & $-0,22732$ & NON DISTRESS \\
\hline ELSA & 2012 & $3 \%$ & $52 \%$ & $137 \%$ & $-1,45816$ & NON DISTRESS \\
\hline
\end{tabular}


Ni Wayan Yulia Krusita, Prediksi Financial Distress...

\begin{tabular}{|c|c|c|c|c|c|c|}
\hline & 2013 & $6 \%$ & $48 \%$ & $160 \%$ & $-1,83608$ & NON DISTRESS \\
\hline & 2014 & $10 \%$ & $39 \%$ & $162 \%$ & $-2,51738$ & NON DISTRESS \\
\hline & 2015 & $9 \%$ & $40 \%$ & $144 \%$ & $-2,4014$ & NON DISTRESS \\
\hline & 2016 & $8 \%$ & $31 \%$ & $149 \%$ & $-2,85926$ & NON DISTRESS \\
\hline & 2017 & $5 \%$ & $37 \%$ & $135 \%$ & $-2,42058$ & NON DISTRESS \\
\hline \multirow[t]{6}{*}{ ENRG } & 2012 & $1 \%$ & $67 \%$ & $67 \%$ & $-0,5625$ & NON DISTRESS \\
\hline & 2013 & $7 \%$ & $62 \%$ & $69 \%$ & $-1,12215$ & NON DISTRESS \\
\hline & 2014 & $1 \%$ & $59 \%$ & $59 \%$ & $-0,98176$ & NON DISTRESS \\
\hline & 2015 & $-19 \%$ & $76 \%$ & $58 \%$ & 0,866572 & DISTRESS \\
\hline & 2016 & $-42 \%$ & $107 \%$ & $63 \%$ & 3,654004 & DISTRESS \\
\hline & 2017 & $2 \%$ & $107 \%$ & $47 \%$ & 1,732694 & DISTRESS \\
\hline \multirow[t]{6}{*}{ ESSA } & 2012 & $6 \%$ & $36 \%$ & $225 \%$ & $-2,54331$ & NON DISTRESS \\
\hline & 2013 & $11 \%$ & $24 \%$ & $324 \%$ & $-3,42665$ & NON DISTRESS \\
\hline & 2014 & $7 \%$ & $28 \%$ & $162 \%$ & $-3,02631$ & NON DISTRESS \\
\hline & 2015 & $2 \%$ & $34 \%$ & $82 \%$ & $-2,43824$ & NON DISTRESS \\
\hline & 2016 & $0 \%$ & $69 \%$ & $234 \%$ & $-0,40135$ & NON DISTRESS \\
\hline & 2017 & $0 \%$ & $74 \%$ & $68 \%$ & $-0,08485$ & NON DISTRESS \\
\hline \multirow[t]{6}{*}{ MEDC } & 2012 & $1 \%$ & $68 \%$ & $265 \%$ & $-0,45228$ & NON DISTRESS \\
\hline & 2013 & $1 \%$ & $65 \%$ & $200 \%$ & $-0,65543$ & NON DISTRESS \\
\hline & 2014 & $1 \%$ & $66 \%$ & $161 \%$ & $-0,5704$ & NON DISTRESS \\
\hline & 2015 & $-6 \%$ & $76 \%$ & $198 \%$ & 0,305633 & DISTRESS \\
\hline & 2016 & $5 \%$ & $75 \%$ & $132 \%$ & $-0,25037$ & NON DISTRESS \\
\hline & 2017 & $3 \%$ & $73 \%$ & $153 \%$ & $-0,27024$ & NON DISTRESS \\
\hline \multirow[t]{6}{*}{ RUIS } & 2012 & $2 \%$ & $80 \%$ & $108 \%$ & 0,1321 & DISTRESS \\
\hline & 2013 & $2 \%$ & $80 \%$ & $119 \%$ & 0,122756 & DISTRESS \\
\hline & 2014 & $4 \%$ & $75 \%$ & $97 \%$ & $-0,20258$ & NON DISTRESS \\
\hline & 2015 & $4 \%$ & $69 \%$ & $87 \%$ & $-0,54046$ & NON DISTRESS \\
\hline & 2016 & $3 \%$ & $63 \%$ & $90 \%$ & $-0,8175$ & NON DISTRESS \\
\hline & 2017 & $2 \%$ & $60 \%$ & $100 \%$ & $-0,9616$ & NON DISTRESS \\
\hline
\end{tabular}

Sumber: Data sekunder diolah, 2018

Perusahaan Ratu Prabu Energi Tbk, Benakat Integra Tbk, Elnusa Tbk, Energi Mega Persada Tbk, Surya Esa Perkasa Tbk dan Medco Energi Internasional Tbk diprediksi tidak mengalami financial distress pada tahun 2012. Hal tersebut dapat dilihat dari hasil perhitungan model zmijewski untuk 6 perusahaan rasio $X$ kurang dari $0(X<0)$ sehingga 6 perusahaan tersebut diprediksi 
berada dalam zona non distress atau tidak mengalami finanial distress sesuai dengan cut off dari model zmijewski.

Prediksi financial distress dengan menggunakan model zmijewski memprediksi Radiant Utama Interinsco Tbk mengalami finanial distress pada tahun 2012. Hal tersebut dapat dilihat dari Tabel 2 diatas debt ratio dari perusahaan ini cukup besar tahun 2012 yaitu sebesar 80 persen artinya bahwa 80 persen total aktiva/total aset perusahaan berasal dari pinjaman atau utang, sehingga perusahaan Radiant Utama Interinsco Tbk akan lebih mudah mengalami financial distress. Perhitungan model zmijewski Radiant Utama Interinsco Tbk juga menunjukkan rasio $\mathrm{X}$ lebih dari $0(\mathrm{X}>0)$ sehingga Radiant Utama Interinsco Tbk tersebut diprediksi berada dalam zona distress sesuai dengan cut off dari model zmijewski.

Perusahaan Ratu Prabu Energi Tbk, Benakat Integra Tbk, Elnusa Tbk, Energi Mega Persada Tbk, Surya Esa Perkasa Tbk dan Medco Energi Internasional Tbk. diprediksi tidak mengalami financial distress pada tahun 2013. Hal tersebut dapat dilihat dari hasil perhitungan model zmijewski untuk 6 perusahaan rasio $\mathrm{X}$ kurang dari $0(\mathrm{X}<0)$ sehingga 6 perusahaan tersebut diprediksi berada dalam zona non distress atau tidak mengalami finanial distress sesuai dengan cut off dari model zmijewski.

Prediksi financial distress dengan menggunakan model zmijewski memprediksi Radiant Utama Interinsco Tbk mengalami finanial distress. Hal tersebut dapat dilihat dari Tabel 2 diatas debt ratio dari perusahaan ini cukup besar tahun 2013 yaitu sebesar 80 persen artinya bahwa 80 persen total 
Ni Wayan Yulia Krusita, Prediksi Financial Distress...

aktiva/total aset perusahaan berasal dari pinjaman atau utang, sehingga perusahaan Radiant Utama Interinsco Tbk akan lebih mudah mengalami financial distress. Perhitungan model zmijewski Radiant Utama Interinsco Tbk juga menunjukkan rasio $\mathrm{X}$ lebih dari $0(\mathrm{X}>0)$ sehingga Radiant Utama Interinsco Tbk tersebut diprediksi berada dalam zona distress sesuai dengan cut off dari model zmijewski.

Prediksi financial distress dengan menggunakan model zmijewski pada tahun 2014 didapatkan hasil bahwa semua perusahaan diprediksi berada pada posisi sehat atau tidak mengalami masalah keuangan. Perusahaan tersebut diprediksi berada pada posisi sehat atau tidak mengalami masalah keuangan karena semua perusahaan tersebut berhasil mempertahankan rasio-rasio keuangan (ROA, debt ratio dan current ratio) perusahannya dengan baik yaitu dengan mengelola aset dengan baik sehingga dapat menghasilkan laba bersih, mampu mengelola seluruh hutang dengan baik dibandingakan dengan total aset dan mampu melunasi kewajiban jangka pendeknya dengan baik. Hasil perhitungan model zmijewski untuk semua perusahaan juga menunjukkan skor $\mathrm{X}$ kurang dari $0(\mathrm{X}<0)$ sehingga semua perusahaan tersebut diprediksi berada dalam zona non distress atau diprediksi tidak mengalami finanial distress sesuai dengan cut off dari model zmijewski.

Perusahaan Ratu Prabu Energi Tbk, Benakat Integra Tbk, Elnusa Tbk, Surya Esa Perkasa Tbk dan Radiant Utama Interinsco Tbk diprediksi tidak mengalami financial distress pada tahun 2015. Hal tersebut dapat dilihat dari hasil perhitungan model zmijewski untuk 5 perusahaan rasio $X$ kurang dari $0(X<0)$ 
sehingga 5 perusahaan tersebut diprediksi berada dalam zona non distress atau tidak mengalami finanial distress sesuai dengan cut off dari model zmijewski.

\section{Perusahaan Energi Mega Persada Tbk (ENRG) dan Medco Energi} Internasional Tbk (MEDC) diprediksi mengalami financial distresspada tahun 2015. Perusahaan tersebut diprediksi mengalami kesulitan keuangan karena ROA kedua perusahaan tersebut mengalami penurunan dibandingkan tahun sebelumnya, bahkan pada tahun 2015 ini kedua perusahaan tersebut memiliki ROA yang negatif atau bisa dikatakan perusahaan tersebut mengalami kerugian, yang artinya perusahaan tersebut tidak mampu memanajemen asetnya dengan baik untuk menghasilkan laba. Hasil perhitungan model zmijewski untuk perusahaan dua perusahaan tersebut juga menunjukkan rasio $X$ lebih dari $0(X>0)$ sehingga perusahaan-perusahaan tersebut diprediksi berada dalam zona distress sesuai dengan cut off dari model zmijewski.

Perusahaan Ratu Prabu Energi Tbk, Elnusa Tbk, Surya Esa Perkasa Tbk, Medco Energi Internasional Tbk dan Radiant Utama Interinsco Tbk diprediksi tidak mengalami financial distress pada tahun 2016. Hal tersebut dapat dilihat dari hasil perhitungan model zmijewski untuk 5 perusahaan rasio $\mathrm{X}$ kurang dari 0 $(\mathrm{X}<0)$ sehingga 5 perusahaan tersebut diprediksi berada dalam zona non distress atau tidak mengalami finanial distress sesuai dengan cut off dari model zmijewski.

Prediksi financial distress menggunakan model zmijewski perusahaan Energi Mega Persada Tbk dan Benakat Integra Tbk diprediksi berada pada posisi distress zone atau mengalami masalah keuangan. Perusahaan Energi Mega Persada Tbk tersebut diprediksi mengalami financial distress kembali seperti 
tahun 2015 dapat dilihat dari ROA perusahaan tersebut yang mengalami penurunan dari tahun sebelumnya yaitu menjadi -42 persen. Perusahaan Benakat Integra Tbk pada tahun ini diprediksi mengalami financial distress karena perusahaan tidak dapat mempertahankan pengelolaan aset dan hal tersebut dapat dilihat dari ROA yang turun cukup besar dari 0 persen menjadi -13 persen yang artinya perusahaan mengalami kerugian akibat tidak mampu mengelola asetnya dengan baik, sehingga pada tahun ini perusahaan Benakat Integra Tbk terindikasi mengalami financial distress. Prediksi financial distress yang dialami Benakat Integra Tbk juga disebabkan karena terjadinya kenaikan pada debt ratio perusahaan dari 66 persen menjadi 77 persen, yang artinya besar aktiva yang dimiliki berasal dari pinjaman, sehingga perusahaan rentan mengalami financial distress. Selain debt ratio prediksi financial distress Benakat Integra Tbk juga disebabkan terjadinya penurunan current ratio perusahaan dari tahun sebelumnya dari 34 persen menjadi 5 persen yang menandakan likuiditas dari perusahaan mengalami penurunan, sehingga perusahaan rentan mengalami financial distress. Hasil perhitungan model ini pada perusahaan Energi Mega Persada Tbk dan Benakat Integra Tbk juga menunjukkan rasio $X$ lebih dari $0(X>0)$ sehingga perusahaan Energi Mega Persada Tbk dan Benakat Integra Tbk tersebut diprediksi berada dalam zona distress sesuai dengan cut off dari model zmijewski.

Perusahaan Ratu Prabu Energi Tbk, Benakat Integra Tbk, Elnusa Tbk, Surya Esa Perkasa Tbk, Medco Energi Internasional Tbk dan Radiant Utama Interinsco Tbk diprediksi tidak mengalami financial distress. Hal tersebut dapat dilihat dari hasil perhitungan model zmijewski untuk 6 perusahaan rasio $\mathrm{X}$ kurang dari 0 
$(\mathrm{X}<0)$ sehingga 6 perusahaan tersebut diprediksi berada dalam zona non distress atau tidak mengalami finanial distress sesuai dengan cut off dari model zmijewski.

Perusahaan Energi Mega Persada Tbk diprediksi berada pada posisi distress zone atau mengalami masalah keuangan pada tahun 2017. Perusahaan Energi Mega Persada Tbk tersebut diprediksi mengalami financial distress kembali seperti tahun 2015 dan 2016 hal itu karena rasio current ratio perusahaan tersebut menurun dari 68 persen menjadi 47 persen yang artinya likuiditas perusahaan tersebut mengalami penurunan dan mengindikasikan perusahaan tersebut tidak sehat, meskipun pada tahun 2017 ini rasio ROA perusahaan tersebut mengalami kenaikan dari -42 persen menjadi 2 persen tetapi hal tersebut tidak terlalu mempengaruhi kondisi perusahaan tersebut menjadi sehat. Hasil perhitungan model zmijewski untuk perusahaan Energi Mega Persada Tbk juga menunjukkan rasio $X$ lebih dari $0(X>0)$ sehingga perusahaan Energi Mega Persada Tbk tersebut berada dalam zona distress sesuai dengan cut off dari model zmijewski

\section{Tabel 2.}

Prediksi Financial Distress menggunakan Model Grover pada Perusahaaan Migas

\begin{tabular}{ccccccc}
\hline Perusahaan & Tahun & $\begin{array}{c}\text { X1 } \\
\text { (WC_TA })\end{array}$ & $\begin{array}{c}\text { X2 } \\
\text { (EBIT_TA) }\end{array}$ & ROA & Grover & Prediksi \\
\hline \multirow{6}{*}{ ARTI } & 2012 & $7 \%$ & $5 \%$ & $4 \%$ & 0,35704 & NON DISTRESS \\
& 2013 & $21 \%$ & $11 \%$ & $4 \%$ & 0,79131 & NON DISTRESS \\
& 2014 & $14 \%$ & $5 \%$ & $2 \%$ & 0,46747 & NON DISTRESS \\
& 2015 & $25 \%$ & $3 \%$ & $1 \%$ & 0,55022 & NON DISTRESS \\
& 2016 & $22 \%$ & $2 \%$ & $0 \%$ & 0,48024 & NON DISTRESS \\
& 2017 & $20 \%$ & $4 \%$ & $1 \%$ & 0,5275 & NON DISTRESS \\
BIPI & 2012 & $15 \%$ & $1 \%$ & $0 \%$ & 0,33288 & NON DISTRESS \\
& 2013 & $-9 \%$ & $7 \%$ & $2 \%$ & 0,14972 & NON DISTRESS \\
& 2014 & $-8 \%$ & $9 \%$ & $2 \%$ & 0,2295 & NON DISTRESS \\
& 2015 & $-21 \%$ & $-1 \%$ & $0 \%$ & $-0,316$ & DISTRESS \\
& 2016 & $-38 \%$ & $-1 \%$ & $-13 \%$ & $-0,5854$ & DISTRESS \\
\hline
\end{tabular}

Bersambung ... 
Ni Wayan Yulia Krusita, Prediksi Financial Distress...

Lanjutan Tabel 2.Prediksi Financial Distress menggunakan Model Grover pada Perusahaaan Migas

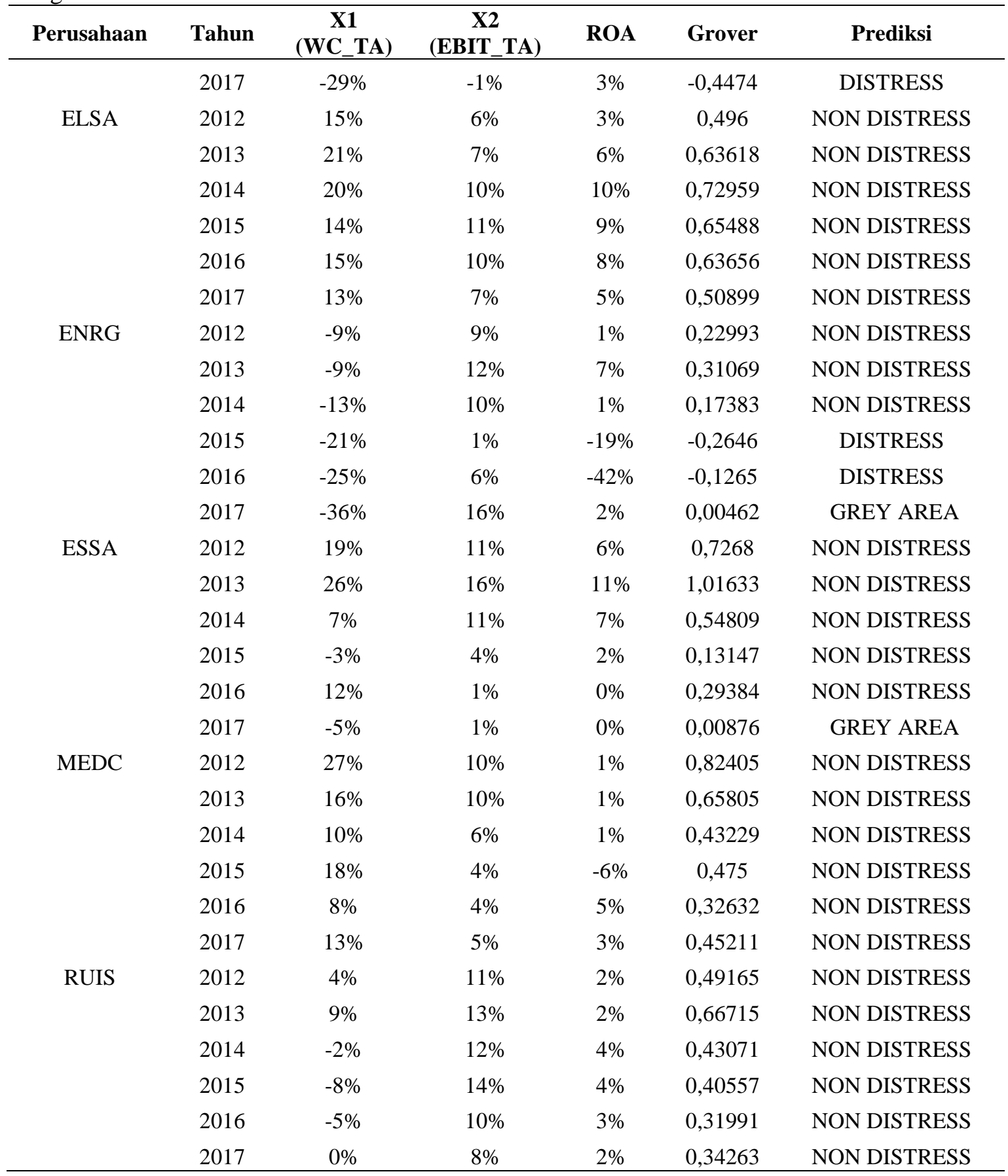

Sumber: Data sekunder diolah, 2018

Prediksi financial distress dengan menggunakan model grover memprediksi semua perusahaan berada pada posisi sehat atau tidak mengalami masalah keuangan pada tahun 2012. Perusahaan tersebut diprediksi berada pada posisi 
sehat atau tidak mengalami masalah keuangan karena semua perusahaan tersebut berhasil mempertahankan rasio-rasio keuangan perusahannya dengan baik yaitu perusahaan memiliki daya untuk membayar kewajiban - kewajiban lancarnya dan menggunakan sisa aktiva untuk kegiatan operasional perusahaan, perusahaan mampu mengelola total aktiva melalui kegiatan operasional perusahaan sehingga dapat menghasilkan laba operasi (laba sebelum pembayaran bunga dan pajak), dan mampu mengelola aset dengan baik sehingga dapat menghasilkan laba. Hasil perhitungan model grover untuk semua perusahaan juga menunjukkan rasio $G \geq$ 0,01 sehingga semua perusahaan tersebut diprediksi berada dalam zona non distress sesuai dengan cut off dari model grover.

Prediksi financial distress dengan menggunakan model grover pada tahun 2013 memprediksi semua perusahaan berada pada posisi sehat atau tidak mengalami masalah keuangan. Perusahaan tersebut diprediksi berada pada posisi sehat atau tidak mengalami masalah keuangan karena tujuh perusahaan tersebut berhasil mempertahankan rasio-rasio keuangan perusahannya dengan baik yaitu perusahaan memiliki daya untuk membayar kewajiban - kewajiban lancarnya dan menggunakan sisa aktiva untuk kegiatan operasional perusahaan, perusahaan mampu mengelola total aktiva melalui kegiatan operasional perusahaan sehingga dapat menghasilkan laba operasi (laba sebelum pembayaran bunga dan pajak), dan mampu mengelola aset dengan baik sehingga dapat menghasilkan laba. Hasil perhitungan model grover untuk semua perusahaan juga menunjukkan rasio $\mathrm{G} \geq$ 0,01 sehingga semua perusahaan tersebut diprediksi berada dalam zona non distress sesuai dengan cut off dari model grover. 
Semua perusahaan diprediksi berada pada posisi sehat atau tidak mengalami masalah keuangan pada tahun 2014. Perusahaan tersebut diprediksi berada pada posisi sehat atau tidak mengalami masalah keuangan karena tujuh perusahaan tersebut berhasil mempertahankan rasio-rasio keuangan perusahannya dengan baik yaitu perusahaan memiliki daya untuk membayar kewajiban - kewajiban lancarnya dan menggunakan sisa aktiva untuk kegiatan operasional perusahaan, perusahaan mampu mengelola total aktiva melalui kegiatan operasional perusahaan sehingga dapat menghasilkan laba operasi (laba sebelum pembayaran bunga dan pajak), dan mampu mengelola aset dengan baik sehingga dapat menghasilkan laba. Hasil perhitungan model grover untuk semua perusahaan juga menunjukkan rasio $\mathrm{G} \geq 0,01$ sehingga semua perusahaan tersebut diprediksi berada dalam zona non distress sesuai dengan cut off dari model grover.

Ratu Prabu Energi Tbk, Elnusa Tbk, Surya Esa Perkasa Tbk, Medco Energi Internasional Tbk dan Radiant Utama Interinso Tbk diprediksi berada pada posisi sehat atau tidak mengalami masalah keuangan pada tahun 2015. Hasil perhitungan model grover untuk semua perusahaan tersebut juga menunjukkan rasio $\mathrm{G}$ lebih besar sama dengan $0,01(\mathrm{G} \geq 0,01)$ sehingga semua perusahaan tersebut diprediksi berada dalam zona non distress sesuai dengan cut off dari model grover.

Benakat Integra Tbk (BIPI) serta Energi Mega Persada Tbk (ENRG) diprediksi mengalami financial distress. Benakat Integra Tbk pada tahun 2015 diprediksi mengalami financial distress karena perusahaan Benakat Integra Tbk pada tahun 2015 mengalami penurunan EBIT_TA (earning before interest and taxes to total assets) yang pada tahun 20149 persen menjadi -1 persen. Selain 
karena rasio EBIT_TA yang menurun prediksi financial distress yang dialami oleh perusahaan Benakat Integra Tbk juga disebabkan karena penurunan WC_TA (working capital to total assets) dari -8 persen menjadi -21 persen pada tahun 2015 dan terjadinya penurunan rasio ROA yaitu dari 2 persen menjadi 0 persen. Energi Mega Persada Tbk pada tahun 2015 diprediksi mengalami financial distress karena perusahaan mengalami penurunan rasio EBIT_TA dari 10 persen menjadi 1 persen. Selain itu juga disebabkan karena penurunan rasio WC_TA dari -13 persen menjadi -21 persen pada tahun 2015 dan juga disebabkan terjadinya penurunan ROA yaitu dari 1 persen menjadi -19 persen. Hasil perhitungan model grover untuk perusahaan Energi Mega Persada Tbk dan Benakat Integra Tbk juga menunjukkan rasio $G \leq-0,02$ sehingga Energi Mega Persada Tbk dan Benakat Integra Tbk tersebut diprediksi berada dalam zona distress sesuai dengan cut off dari model grover.

Perusahaan Ratu Prabu Energi Tbk, Elnusa Tbk, Surya Esa Perkasa Tbk, Medco Energi Internasional Tbk dan Radiant Utama Interinso Tbk diprediksi berada pada posisi sehat atau tidak mengalami masalah keuangan. Hasil perhitungan model grover untuk semua perusahaan tersebut juga menunjukkan rasio $G$ lebih besar sama dengan $0,01(G \geq 0,01)$ sehingga semua perusahaan tersebut diprediksi berada dalam zona non distress sesuai dengan cut off dari model grover.

Benakat Integra Tbk (BIPI) dan Energi Mega Persada Tbk (ENRG) diprediksi mengalami financial distress (kesulitan keuangan). Benakat Integra Tbk pada tahun 2016 diprediksi mengalami financial distress kembali seperti 
tahun 2015 karena perusahaan Benakat Integra Tbk pada tahun 2016 memiliki rasio EBIT_TA yang sama dengan pada tahun 2016 yaitu sebesar -1 persen, juga disebabkan karena penurunan rasio WC_TA dari -21 persen menjadi -38 persen pada tahun 2016, dan terjadinya penurunan rasio ROA yaitu dari 0 persen menjadi -13 persen. Energi Mega Persada Tbk pada tahun 2016 diprediksi mengalami financial distress karena perusahaan Energi Mega Persada Tbk mengalami penurunan rasio WC_TA dari -21 persen menjadi -25 persen pada tahun 2016, terjadinya penurunan rasio ROA yaitu dari -19 persen menjadi -42 persen dan hasil perhitungan model grover untuk perusahaan Energi Mega Persada Tbk dan Benakat Integra Tbk yang menunjukkan rasio $G \leq-0,02$ sehingga perusahaan Energi Mega Persada Tbk dan Benakat Integra Tbk diprediksi berada dalam zona distress sesuai dengan cut off dari model grover.

Perusahaan Ratu Prabu Energi Tbk, Elnusa Tbk, Medco Energi Internasional Tbk dan Radiant Utama Interinso Tbk diprediksi berada pada posisi sehat atau tidak mengalami masalah keuangan. Hasil perhitungan model grover untuk semua perusahaan tersebut juga menunjukkan rasio $\mathrm{G}$ lebih besar sama dengan $0,01(\mathrm{G} \geq 0,01)$ sehingga semua perusahaan tersebut diprediksi berada dalam zona non distress sesuai dengan cut off dari model grover.

Prediksi financial distress dengan menggunakan model grover pada tahun 2017 memprediksi Benakat Integra Tbk mengalami financial distress. Benakat Integra Tbk pada tahun 2017 diindikasikan mengalami financial distress kembali seperti 2 tahun sebelumnya karena perusahaan Benakat hasil perhitungan hasil perhitungan model grover untuk perusahaan Benakat Integra Tbk menunjukkan 
rasio $\mathrm{G} \leq-0,02$ sehingga Benakat Integra Tbk tersebut diprediksi berada dalam zona distress sesuai dengan cut off dari model grover mespkipun perusahaan telah dapat menaikan rasio EBIT_TA, WC_TA, dan ROA. Pada tahun 2017 ini terdapat 2 perusahaan yang diprediksi berada pada posisi grey zone yaitu perusahaan Energi Mega Persada Tbk (ENRG) serta perusahaan Surya Esa Perkasa Tbk (ESSA). Perusahaan ENRG masuk grey zone karena hasil perhitungan model grover untuk perusahaan Energi Mega Persada Tbk rasio G berada pada batas atas dan bawah cut off model grover. Surya Esa Perkasa Tbk tersebut diprediksi berada dalam zona grey area pada tahun 2017 karena hasil perhitungan model grover untuk perusahaan Surya Esa Perkasa Tbk juga menunjukkan rasio G berada pada batas atas dan bawah cut off model grover.

\section{SIMPULAN DAN SARAN}

Simpulan penelitian ini adalah hasil prediksi dengan menggunakan model Zmijewski tahun 2012 dan 2013 diprediksi Radiant Utama Interinsco Tbk mengalami financial distress, pada tahun 2014 semua perusahaan diprediksi dalam keadaan sehat, pada tahun 2015 Energi Mega Persada Tbk (ENRG) serta Medco Energi Internasional Tbk (MEDC) diprediksi mengalami financial distress, pada tahun 2016 Energi Mega Persada Tbk dan Benakat Integra Tbk diprediksi mengalami financial distress dan pada tahun 2017 Energi Mega Persada Tbk diprediksi mengalami financial distress. Hasil prediksi financial distress menggunakan model Grover dari tahun 2012-2014 semua perusahaan diprediksi sehat, pada tahun 2015 serta tahun 2016 Benakat Tbk dan Energi Mega Persada Tbk diprediksi mengalami financial distress dan pada tahun 2017 
Benakat Integra Tbk diprediksi terdapat satu perusahaan yang mengalami financial distress serta Energi Mega Persada Tbk (ENRG) dan Surya Esa Perkasa Tbk (ESSA) diprediksi berada pada grey area. Hasil prediksi model zmijewski serta model grover dalam memprediksi financial distress menghasilkan prediksi yang sama yaitu perusahaan Energi Mega Persada Tbk diprediksi mengalami financial distress pada tahun 2015 dan tahun 2016.

Penelitian ini memiliki keterbatasan memprediksi financial distress hanya menggunakan model Grover dan model Zmijewski, sehingga disarankan bagi penelitian selanjutnya yang ingin melakukan penelitian sejenis agar menggunakan model prediksi financial distress lainnya seperti model Altman Z-score, model ohlson, model springate, model CA-score, model fulmer atau model lainnya serta memperluas cakupan perusahaan yang diteliti agar mendapatkan hasil penelitian yang lebih baik.

\section{REFERENSI}

Ambarwati, Umi, Sudarwati \& Rochmi Widayanti. (2017). Financial Distress dengan Metode Springate, Zmijewski, Fulmer dan Altman Z-Score Pada PT Tunas Baru Lampung Tbk Di BEI. JSSH (Jurnal Sains Sosial dan Humaniora), 1(1), hal. 1-15.

Aminian, Abolfazl, Hedayat Mousazade \& Omid Imani Khoshkho. (2016). Investigate the Ability of Bankruptcy Prediction Models of Altman and Springate and Zmijewski and Grover in Tehran Stock Exchange. Mediterranean Journal of Social Sciences, 7(4), pp 207-214.

Avenhuis, Jeroen O. (2013). Testing the Generalizability of the Bankruptcy Prediction Models of Altman, Ohlson, and Zmijewski for Dutch Listed and Large Non-Listed Firms. Journal of School of Management and Governance University of Twente.

Bursa Efek Indonesia. (2018). IDX Yearly Statistics 2012-2017. Jakarta:IDX 
Desmawati, Kamaliah \& Errin Yani Wijaya. (2016). Analisis Prediksi Kebangkrutan Dengan Model Altman, Springate, Grover \& Zmijewski Pada Industri Manufaktur Di BEI. Jurnal Tepak Manajemen Bisnis, 8 (2), hal. 119.

Dewi, Ni Komang Uttami Ghita \& Made Dana. (2017). Variabel Penentu Financial Distress Pada Perusahaan Manufaktur Di Bursa Efek Indonesia. EJurnal Manajemen Unud, 6 (11), hal 5834-5858.

Djamaluddin, Said, Melati Juwita Putridan \& Hapzi Ali. (2017). Financial Distress Comparative Analysis of Japanese Electronic Manufacturer after Financial Global Crisis 2008 Using Altman, Ohlson, and Zmijewski Model. The International Journal Of Business \& Management, 5 (7), pp. 131-141.

Fatmawati, Mila. (2012). Penggunaan The Zmijewski Model, The Altman Model, Dan The Springate Model Sebagai Prediktor Delisting. Jurnal Keuangan dan Perbankan, 16 (1), hal. 56-65.

Grover, J. (2003). Validation of A Cash Flow Model: A Non-Bankruptcy Approach. Ph.D. Disertasi, Nova Southeastern University.

Hidayat, Muhammad Arif \& Wahyu Meiranto. (2014). Prediksi Financial Distress Perusahaan Manufaktur di Indonesia. Diponegoro Journal of Accounting, 3 (3), hal. 1-11.

Husein, M Fakhri \& Galuh Tri Pambekti. (2014). Precision of The Models of Altman, Springate, Zmijewski, and Grover for Predicting The Financial Distress. Journal of Economics, Business, and Accountancy Ventura, 17 (3), pp. $405-416$

Januri, Eka Nurmala Sari \& Armida Diyanti. (2017). The Analysis Of The Bankruptcy Potential Comparative By Altman Z-Score, Springate And Zmijewski Methods At Cement Companies Listed In Indonesia Stock Exchange. IOSR Journal of Business and Management (IOSR-JBM), 19 (10), pp. 80-87.

Kleinert, Mareike Kira. (2014). Comparison of Accounting-Based Bankruptcy Prediction Models Of Altman (1968), Ohlson (1980), And Zmijewski (1984) To German And Belgian Listed Companies During 2008 - 2013. Master Tesis. University Of Twente, The Netherlands Institution Faculty Of Management And Governance.

Kordestani, Gholamreza, Vahid Biglari \& Mehrdad Bakhtiari. (2011). Ability Of Combinations of Cash Flow Components to Predict Financial Distress. Business: Theory and Practice, 12(3), pp. 277-285. 
Kurniawati, Lintang \& Nur Kholis. (2016). Analisis Model Prediksi Financial Distress pada Perusahaan Perbankan Syariah di Indonesia. Seminar Nasional dan The 3rd Call for Syariah Paper FEB UMS. Surakarta.

Margali, Giovanni Edward, Paulina Van Rate \& Joubert B Maramis. (2017). Analisis Akurasi Model Prediksi Financial distress Altman, Springate, Ohlson dan Grover (Studi Kasus pada Perusahaan PT. Dayaindo Resources International Tbk dan PT. Surabaya Agung Industri Kertas dan Pulp Tbk yang telah bangkrut). Jurnal EMBA 5 (2), hal. 1493 -1502.

Oktaviandri, Annisa, Anisah Firli \& Aldilla Iradianty. (2016). Analisis Prediksi Kebangkrutan Dengan Model Altman, Springate, Ohlson, dan Grover Pada Perusahaan Di Sektor Pertanian Bursa Efek Indonesia Periode 2011 - 2015. Majalah Ilmiah UNIKOM, 15 (1), hal. 71-78.

Pakdaman, Hasan. (2018). Investigating the Ability of Altman and Springate and Zmijewski and Grover Bankruptcy Prediction Models in Tehran Stock Exchange. Revista ESPACIOS, 39(14), pp. 33.

Priambodo, Dimas. (2017). Analisis Perbandingan Model Altman, Springate, Grover, dan Zmijewski dalam Memprediksi Financial Distress (Studi Empiris pada Perusahaan Sektor Pertambangan yang Terdaftar di Bursa Efek Indonesia Periode 2012-2015). Jurnal Pendidikan Akuntansi, hal. 1-10.

Prihanthini, Ni Made Evi Dwi \& Maria M. Ratna Sari. (2013). Prediksi Kebangkrutan dengan Model Grover, Altman Z-Score, Springate, dan Zmijewski Pada Perusahaan Food and Beverages Di Bursa Efek Indonesia”. E-jurnal Akuntansi Universitas Udayana, 5 (2), hal. 417-435.

Primasari, Niken Savitri. (2017). Analisis Altman Z-score, Grover Score, Springate, dan Zmijewski sebagai Signaling Financial Distress (Studi Empiris Industri Barang-Barang Konsumsi Indonesia). Accounting and Management Journal, 1 (1), hal. 23-43.

Putera, Fairuz Zabady Zainal Abidin, Fifi Swandari \& Dian Masita Dewi. (2016). Perbandingan Prediksi Financial Distress dengan Menggunakan Model Altman, Springate Dan Ohlson. Jurnal Wawasan Manajemen, 4 (3), hal. 217-229.

Putra, Tri Utama \& Arlin Ferlina Moch T. (2014). Analisis Prediksi Tingkat Kebangkrutan dengan Metode Altman Z-Score dan Springate (Studi Kasus pada perusahaan Sub Sektor Perambangan Minyak dan Gas Bumi yang Tercatat Di Bursa Efek Indonesia Tahun 2009-2012). Jurnal Studi Manjemen dan Bisnis, 1 (2), hal. 1-13. 
Putra, Ivan Gumilar Sambas \& Rahma Septiani. (2016). Analisis Perbandingan Model Zmijewski dan Grover pada Perusahaan Semen di BEI 2008-2014. Jurnal Riset Akuntansi dan Keuangan, 4 (3), hal. 1143-1154.

Salim, M. Noor \& Sudiono. (2017). An Analysis Of Bankruptcy Likelihood On Coal Mining Listed Firms In The Indonesian Stock Exchange: An Altman, Springate And Zmijewski Approaches. Eurasian Journal of Economics and Finance, 5(3), pp. 99-108.

Simanjuntak, Christon, Farida Titik \& Wiwin Aminah. (2017). Pengaruh Rasio Keuangan terhadap Financial Distress (Studi pada Perusahaan Transportasi yang Terdaftar di Bursa Efek Indonesia periode 2011- 2015). E-Proceeding Of Management, 4 (2), hal. 1580-1587.

SKK Migas. (2018). Produksi Minyak dan Gas Bumi 2012-2017. Jakarta: SKK Migas

Wiagustini, Ni Luh Putu. (2014). Dasar-Dasar Manajemen Keuangan. Denpasar: Udayana University Press

Wulandari, Veronita, Emrinaldi, Nur DP \& Julita. (2014). Analisis Perbandingan Model Altman, Springate, Ohlson, Fulmer, CA-Score dan Zmijewski Dalam Memprediksi Financial Distress (Studi Empiris pada Perusahaan Food and Beverages yang Terdaftar di Bursa Efek Indonesia Periode 2010-2012). JOM FEKON, 1 (2), hal. 1-18.

Xie, Chi, Changqing Luo \& Xiang Yu. (2010). Financial distress prediction based on SVM and MDA methods: the case of Chinese listed companies. Qual Quant, 45, pp. 671-686.

Zmijewski, M. E. (1984). Methodological Issues Related to the Estimation of Financial Distress Prediction Models. Journal of Accounting Research, 22(1), pp. 59-82. 